\title{
Source Apportionment and Elemental Composition of Atmospheric Total Suspended Particulates (TSP) Over the Red Sea Coast of Saudi Arabia
}

\author{
M. Cusack' ${ }^{1}$ J. M. Arrieta ${ }^{2} \cdot$ C. M. Duarte ${ }^{1}$ D
}

Received: 10 October 2020 / Accepted: 12 November 2020 / Published online: 24 November 2020

(c) The Author(s) 2020

\begin{abstract}
This work presents a comprehensive study on concentrations and elemental composition of total suspended atmospheric particulates for a semi-urban site on the Red Sea coast, and on-board a research vessel, which collected off-shore samples along the Red Sea. We conducted one of the most extended measurement campaigns of atmospheric particulates ever for the region, with continuous measurements over 27 months. The overall mean concentrations ( \pm st. dev.) of TSP were $125 \pm 197 \mu \mathrm{g} \mathrm{m}^{-3}$ for the permanent semi-urban site, and $108 \pm 193 \mu \mathrm{g} \mathrm{m}{ }^{-3}$ for the off-shore mobile site. The region is frequently severely impacted by both localised and widespread dust storms, which on occasion, can increase atmospheric particulate concentrations to levels above $\mathrm{mg} \mathrm{m}^{-3}\left(>1000 \mu \mathrm{g} \mathrm{m}^{-3}\right.$ ). Median concentrations were not as variable between seasons, indicating a stable, permanent presence of atmospheric particulates independent of the time of year. The primary chemical elements contributing to particulate mass were $\mathrm{Na}, \mathrm{Ca}, \mathrm{S}, \mathrm{Al}$ and $\mathrm{Fe}$. We employed Positive Matrix Factorisation (EPA PMF v5.0.14) to identify different major sources of particulates, which were crustal, marine, fuel oil combustion/secondary sulphate and mixed anthropogenic. The crustal source was characterised by tracers $\mathrm{Al}, \mathrm{Fe}, \mathrm{K}, \mathrm{Mg}$ and $\mathrm{Sn}$, and was present to some extent in the other identified sources due to the permanent presence of dust particles in the atmosphere. The fuel oil combustion/ secondary sulphate source was identifiable by the almost exclusive presence of $\mathrm{S}$, and to a lesser extent $\mathrm{V}$, emitted from oil combustion as primary emissions and also secondary sulphate formation following the release of $\mathrm{S}$ to the atmosphere. A mixed anthropogenic source was characterised by $\mathrm{Zn}, \mathrm{Ni}, \mathrm{Cr}, \mathrm{Cu}$ and $\mathrm{Pb}$, emitted from traffic, industry, power generation and water desalination. This study highlights that the natural sources of particulates in this desert region give rise to frequent episodes of extremely poor air quality, and this problem is compounded by significant emissions of anthropogenic pollution, which has an impact across the entire Red Sea basin. Further stringent measures should be adopted to improve air quality across the region and prevent long-term damage to the health of the local population and ecosystems.
\end{abstract}

Keywords Atmospheric pollution $\cdot$ Red Sea $\cdot$ Middle east $\cdot$ Source apportionment $\cdot$ Atmospheric dust

\section{Introduction}

The negative impacts of atmospheric particulate matter (PM) have been the focus of considerable research, given the effects of exposure to air pollution on human health (Pope

C. M. Duarte

carlos.duarte@kaust.edu.sa

1 Red Sea Research Centre and Computational Bioscience Research Center, King Abdullah University of Science and Technology, Thuwal 23955-6900, Saudi Arabia

2 Oceanographic Center of the Canary Islands, Spanish Institute of Oceanography (IEO), 38180 Santa Cruz de Tenerife, Spain et al. 2002; Valavanidis et al. 2008; Lelieveld et al. 2015), and the role of PM in climate change and the hydrological and biogeochemical cycles (Ramanathan and Carmichael 2008; Ramanathan et al. 2001). Atmospheric particles also have the potential to impact ecosystems both negatively and positively, such as in the oligotrophic Red Sea, where desert dust deposition is believed to be a major source of nutrients (Acosta et al. 2013, Jish Prakash et al. 2015). Atmospheric aerosols contain a complex mixture of various compounds, such as crustal material and minerals, elemental (graphitic) and organic carbon, secondary inorganic compounds and heavy metals. The chemical composition of atmospheric PM is largely governed by geographic location and local or large-scale sources (National Research Council [NRC] 
2004). Mineral dust, i.e., atmospheric particles of crustal origin, is the most abundant atmospheric aerosol and is primarily composed of resuspended soils and sand from arid and semi-arid regions of the globe (Goudie and Middleton 2006; Mahowald et al. 2014), especially the Sahara desert and Arabian Peninsula (Edgell 2006). Indeed, the Arabian Peninsula is considered one of the significant sources of atmospheric dust on a global scale, contributing as much as $12 \%$ of the global total dust emissions to the atmosphere (1877-4000 megatonnes per year; Tanaka and Chiba 2006; Engelbrecht et al. 2017). The aridity of the Arabian Peninsula gives rise to extreme levels of windborne mineral dust and can result in frequent local and widespread dust storms. Jish Prakash et al. 2015 recently estimated that the Red Sea region experiences five to six major dust events annually, depositing up to $5 \mathrm{Mt}$ of dust particles into the Red Sea. The direct impact of these dust deposits on Red Sea ecosystems has yet to be determined conclusively, as they may involve a range of processes depending on the bioavailability of associated nutrients and the toxicity of metals and pollutants associated with the dust particles. However, indirect effects will undoubtedly impact the region. For example, such elevated atmospheric dust concentrations have been shown to impact the surface energy budget over the Peninsula and the Red Sea (Kalenderski et al. 2013; Osipov et al. 2015; Brindley et al. 2015). The Red Sea is one of the warmest bodies of water in the world and is already significantly thermally stressed, with rapidly rising temperatures as a result of climate change (Chaidez et al. 2017). Any changes in atmospheric particulate concentrations and chemical composition could impact radiative forcing over the Red Sea, which in turn would have a severe impact on the region, having a net cooling or net heating effect over an already climatically vulnerable region of the globe (Jish Prakash et al. 2015).

Studies on PM over the Arabian Peninsula and in the Red Sea basin are currently limited relative to the rest of the world, despite the global significance of these regions as a source and recipient of atmospheric particles, respectively, with most studies being based on remote sensing data products (Hsu et al. 2004; Brewin et al. 2015; Şen 2018). However, a few recent studies have emerged describing atmospheric aerosol processes and dynamics on the Saudi Arabian coastline of the Red Sea and for the urban area of Jeddah (Aburas et al. 2011; Khodeir et al. 2012; Alghamdi et al. 2014; Lim et al. 2018; Harrison et al. 2017). These studies found that naturally occurring desert dust storms caused severe air pollution across the region, creating extremely elevated levels of atmospheric particles. However, major anthropogenic emission sources are also present along the Red Sea coast, from traffic emissions, incineration, power generation, desalination plants and residual oil burning, exacerbating an already polluted atmosphere (Lim et al. 2018).
This current study aims to expand on the limited knowledge of atmospheric pollution for the Arabian Peninsula by reporting total suspended particulates (TSP) and associated metal concentrations over the Red Sea coast of Saudi Arabia. We describe the variability of ambient concentrations of TSP over almost 2.5 years at a permanent location on the Red Sea coast and simultaneously at a mobile station on a research vessel collecting samples along the entire Saudi Red Sea. We describe and compare the variability of metal concentrations in TSP from both the permanent and mobile sites. Finally, we identify and quantify the contribution of a number of different sources of metals to the atmosphere across the region.

\section{Data and Methodology}

\subsection{Sampling Site}

We performed regular sampling of TSP for gravimetric analysis between September 2015 and December 2017 at two locations: one permanent and one mobile site. The permanent sampling site was located on the shore of the Red Sea within the grounds of King Abdullah University of Science and Technology (KAUST; $22^{\circ} 19^{\prime} 07.3^{\prime \prime} \mathrm{N}, 39^{\circ} 06^{\prime} 10.5^{\prime \prime}$ E; 1 m.a.s.l., Fig. 1), in a quiet residential area of the university campus, $30 \mathrm{~m}$ from the nearest road with very light traffic flow and $50 \mathrm{~m}$ from the shore of the Red Sea. Local emissions from within and around the university campus are likely to be minimal, with relatively low traffic flow, no domestic heating emissions or biomass burning, and the nearest motorway is located around $6 \mathrm{~km}$ inland from the site. The Red Sea coastal region experiences a typical desert climate characterized by consistently high temperatures during summer, accompanied with relative humidity as high as $85 \%$, and night-time temperatures rarely drop much below $30{ }^{\circ} \mathrm{C}$. Rainfall for the region is very low, measured at $56 \mathrm{~mm}$ annually in Jeddah, falling almost exclusively during the autumn and winter months (http://worldweather.wmo.int/ en/city.html?cityId=699). When rain does occur, it comes in severe bursts of short duration, often during thunderstorms, and can cause flash floods (de Vries et al. 2013). During such events, fine silt and clay deposits are washed to the coastal plains and wadis, which in turn become a significant local source of dust particles during dry and windy periods (Engelbrecht et al. 2017). Wind trajectories along the Red Sea usually travel parallel to the coast along a north-westerly trajectory (Harrison et al. 2016). Vegetation is sparse owing to the harsh environment and low precipitation and is limited to desert shrubs, with minimal capacity to trap and hold soil and dust particles. At our sampling location, as for most of the northern and mid-Red Sea coast, a persistent NW wind prevails during all seasons but is most active during 
Fig. 1 Wind roses $\left(\mathrm{m} \mathrm{s}^{-1}\right)$ for each season between September 2015 and December 2017 at the permanent sampling site KAUST

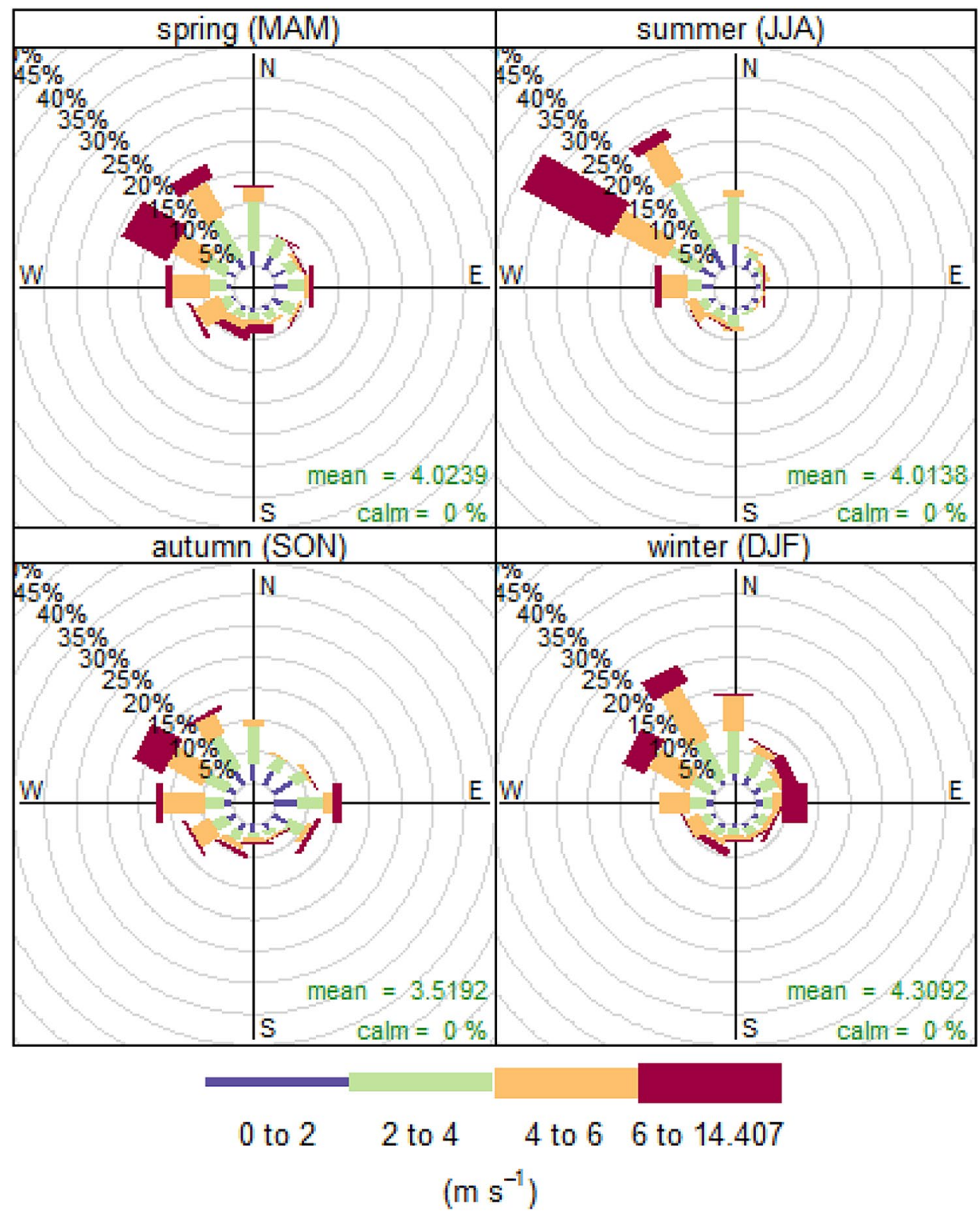

Frequency of counts by wind direction (\%)

the summer months (Fig. 2). Winds originating from the east occurred almost exclusively during winter, and to a lesser extent in autumn, and, although infrequent, easterly winds tended to be relatively strong winds $\left(6-14 \mathrm{~m} \mathrm{~s}^{-1}\right.$; Fig. 2). One potentially major source of air pollution is located around $50 \mathrm{~km} \mathrm{~N}$ of our site from the Rabigh Refining and Petrochemical Company, which produces naphtha, kerosene, gasoline, diesel and fuel oil. Moreover, NW winds travelling parallel to the coast cross Yanbu, which is an important site of industrial activity with three oil refineries, a plastics facility and other petrochemical plants, and is an important shipping terminal. More locally, coastal breezes carry and disperse emissions inland from the industrial site of Rabigh, but on calm days, a pollution haze is clearly visible, stretching out over the Red Sea and reducing visibility.

The mobile sampling station was located on-board the research vessel Thuwal, around 7.5 m.a.s.l., during 13 cruises between February 2016 and July 2017, covering the entire Red Sea from the Gulf of Aqaba in the north to the Farasan Banks in the south. The research cruises navigated only within Saudi Arabian territorial waters and included coastal and pelagic (open sea) studies. Sampling was programmed to be continuous for the duration of each cruise (typically one to two weeks) and included periods when the RV was travelling between sites and stationary. Further details on the research vessel can be found in the 
Fig. 2 Monthly mean \pm SD and median conc. of TSP $\left(\mu \mathrm{g} \mathrm{m}^{-3}\right)$ per month for a permanent and b mobile stations. Off scale SD values given above bar. The dashed black line is the annual mean, and the dashed orange line is the annual median
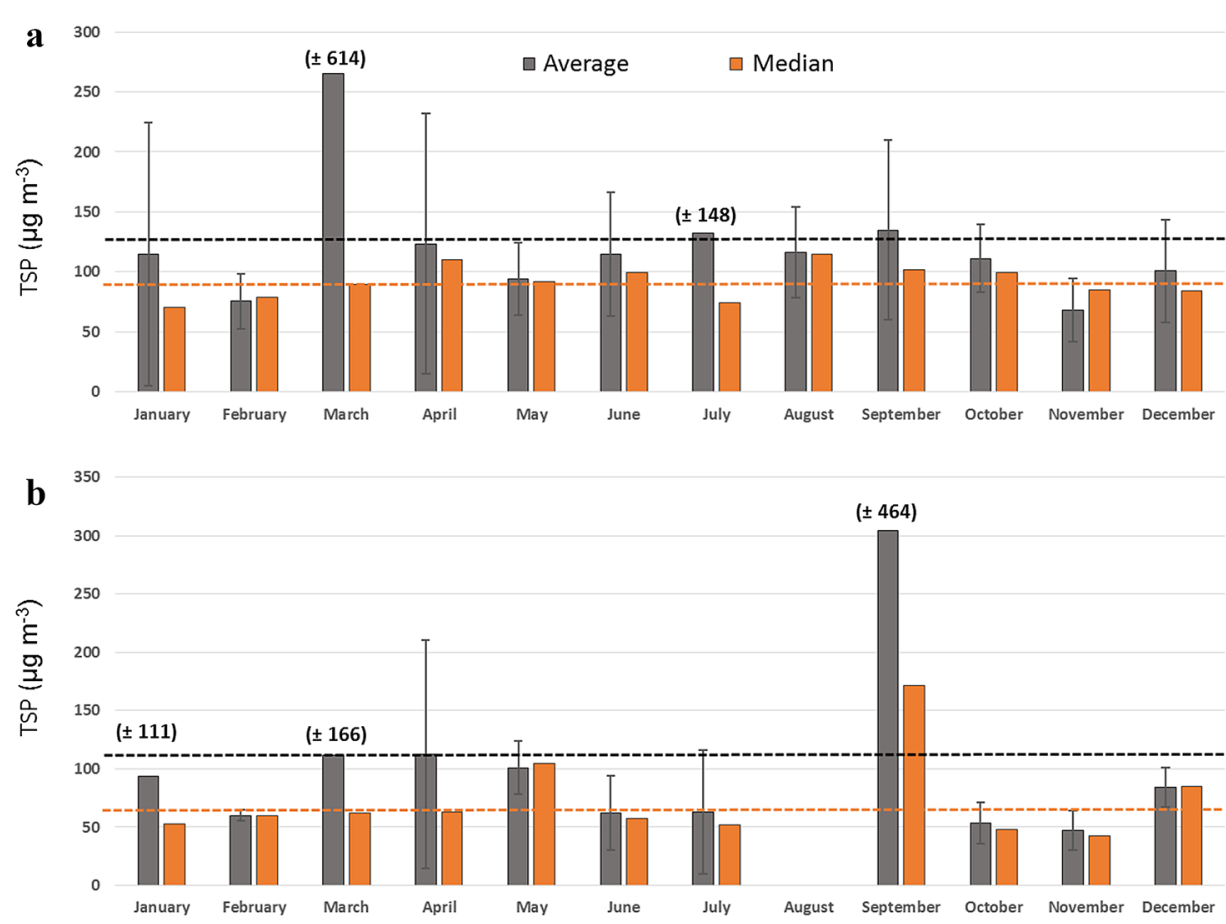

following link: https://cmor.kaust.edu.sa/Pages/R\%20 V\%20Thuwal.aspx.

\subsection{Sampling Procedure}

Regular samples of TSP were collected using automatic sequential high-volume samplers (MCV-CAV) equipped with TSP sampling heads, thus collecting all airborne particulates. The high-volume samplers were equipped with in-built pumps set at a flow rate of $20 \mathrm{~m}^{3} \mathrm{~h}^{-1}$. Samples were collected for a duration between 24 and $72 \mathrm{~h}$. The sampler on-board the research vessel was equipped with a wind vane that was programmed to cease sampling immediately whenever the sampler was downwind of the ship's exhaust, thus preventing contamination. We collected 157 samples on acid-treated low-metal glass microfiber filters (Whatman $150 \mathrm{~mm}$ diameter) at the permanent station, and 81 samples at the mobile station. We used Whatman filters until Dec 2016, and from Jan 2017, we used Quartz microfiber filters (Grade QM-A). Sampling was scheduled at both sites simultaneously when the mobile station was operating. We weighed the filters before sampling at ambient temperature and relative humidity $\left(21^{\circ} \mathrm{C}\right.$ and $\left.60 \% \mathrm{RH}\right)$. Following sampling, we weighed the filters three times at ambient temperature and relative humidity. We determined TSP mass concentrations by standard gravimetric procedures, and we report concentrations as $\mu \mathrm{g} \mathrm{m}^{-3}$. We performed chemical analysis for metal concentrations in TSP by Inductively Coupled Plasma Optical Emission Spectrometry (ICP OES). Half of each filter was acid-digested (HF: $\mathrm{HNO}_{3}$ :
$\mathrm{HCl}$ ) in a microwave oven (Milestone Ethos 1) at $200{ }^{\circ} \mathrm{C}$ for $15 \mathrm{~min}$. The digestion solution was then diluted to $50 \mathrm{ml}$ and analysed by ICP-OES (Varian 720-ES). Reagent blanks, replicates and standard reference material 1646a from the National Institute of Standards and Technology were routinely analysed to ensure the accuracy of digestion and analytical procedures. All samples were blank filter-corrected. Concentrations of $\mathrm{Al}, \mathrm{As}, \mathrm{Ca}, \mathrm{Cd}, \mathrm{Cr}, \mathrm{Cu}, \mathrm{Fe}, \mathrm{K}, \mathrm{Mg}, \mathrm{Mn}$, $\mathrm{Na}, \mathrm{Ni}, \mathrm{P}, \mathrm{PB}, \mathrm{S}, \mathrm{Sb}, \mathrm{Sn}, \mathrm{Sr}, \mathrm{V}$ and $\mathrm{Zn}\left(\mu \mathrm{g} \mathrm{m}^{-3}\right)$ were determined for each filter sample.

We calculated enrichment factors (EF) for each element to determine their abundance in the atmosphere relative to their natural background levels in the environment. High values of $\mathrm{EF}$ for a given element indicate elements that are mobilised in the environment as a result of anthropogenic activities. The enrichment factor is defined as $\mathrm{EF}_{x}=(X / Y)_{\text {air }}$ I $(X / Y)_{\text {crust }}$, where $X$ is the concentration of the target element and $Y$ is the concentration of the reference element in the air and in the earth's crust. In this study, we used the average concentration of $\mathrm{Fe}$ in soil samples $\left(64.6 \mathrm{mg} \mathrm{kg}^{-1}\right)$ measured across the entire Arabian Peninsula reported by Jish Prakash et al. 2016 as the reference element, and the earth crustal chemical composition for the analysed metals was taken from Hu and Gao (2008).

\subsection{Source Apportionment}

We performed source apportionment analysis on the data set of TSP and metal concentrations using Environmental Protection Agency Positive Matrix Factorization (EPA PMF) 
v5.0.14 software. PMF is a multivariate factor analysis tool that decomposes a matrix of speciated sample data into two matrices-factor contributions and source profiles-which are then interpreted as the type of source using measured source profile information. Individual estimates of the uncertainty associated with each data value are required because PMF is a weighted least-squares method. We determined the individual estimates of uncertainty in the data set following the methodology described in (Amato et al. 2009). We selected the metals used in this work according to their signal-to-noise ratio $(S / N)$, whereby we defined species with $S / N<2$ as weak source indicators and we categorised species with $S / N>2$ as strong source indicators. The $S / N$ ratio is calculated automatically by the PMF software for each element. These criteria resulted in 16 strong species and three weak species. We set TSP as the "total variable", which was thus automatically categorised as weak, increasing the uncertainty of this variable threefold, to avoid affecting the PMF solution. We performed PMF on two data sets from the permanent and mobile sites. The permanent site matrix included 157 cases, and the mobile (off-shore) site matrix included 81 cases. After we tested a variety of factor numbers, we found a four-factor solution provided the most meaningful results, giving a coefficient of determination $\left(R^{2}\right)$ of 0.7 between the modelled and measured TSP concentrations and $Q$ values of 2366 (robust) and 2960 (true). We investigated these $Q$ values for different FPEAK values, with FPEAK $=0$ found to be the most reasonable. We also performed 100 bootstrap runs with a minimum of $R^{2}$ of 0.6 to test the uncertainty of the resolved profiles, with all four factors being mapped, verifying the stability of the results.

\section{Results and Discussion}

The mean \pm SD concentrations of TSP for the measurement period of Sept 2015 to Dec 2017 for the permanent landbased site were $125 \pm 197 \mu \mathrm{g} \mathrm{m}^{-3}$ (Table 1; Fig. 2.). Average concentrations for the mobile off-shore measurements (Feb 2016 to July 2017) were comparable at $108 \pm 193 \mu \mathrm{g} \mathrm{m} \mathrm{m}^{-3}$ (Table 1). Intense peaks in concentrations heavily skewed the mean TSP concentrations as a result of dust storms and elevated periods of pollution, as evidenced by median concentrations of 89 and $63 \mu \mathrm{g} \mathrm{m}{ }^{-3}$ for the permanent and mobile sites, respectively, i.e., much lower than the mean TSP values. The extreme concentrations recorded in March were probably due to local emission sources, specifically from the petrochemical plant located near the permanent station. Emissions from the petrochemical plant can severely impact the region on days with weak or no sea breezes. When the thermal gradient between the land and sea is reduced, the local sea breezes are consequently less active, causing the air to stagnate across the area and pollution from the petrochemical plant to reach the sampling site. On a seasonal basis, spring experienced the highest mean concentrations of $164 \pm 365 \mu \mathrm{g} \mathrm{m}^{-3}$ (Table 1; Fig. 2).

Relative to the mean concentrations, median concentrations at both sampling sites are remarkably similar throughout the year, with less variability between months (Fig. 2) and seasons (Table 1), indicating a stable presence of background levels of atmospheric particles throughout the year, independent of specific dust storm events. The minimum $\left(11 \mu \mathrm{g} \mathrm{m}^{-3}\right)$ and maximum concentrations $\left(2389 \mu \mathrm{g} \mathrm{m}^{-3}\right)$ at the permanent site were both recorded during spring, indicating this to be the season experiencing the most extreme dust and clean air events during the year. We recorded the highest concentrations of TSP during all the research cruises (> $600 \mu \mathrm{g} \mathrm{m}^{-3}$; Fig. 3) on 27/9/2016 (1619 $\mu \mathrm{g} \mathrm{m}^{-3}$ ), which occurred during an intense urban pollution episode compounded by a weak dust storm event. During this sampling period, the research vessel was located in the central Red Sea, within the vicinity of the densely populated urban area of Jeddah, which is, in itself, a significant source of air pollution. We observed peaks in metal concentrations for crustal elements ( $\mathrm{Al}, \mathrm{Fe}, \mathrm{Mn}, \mathrm{Sn}$ ) in tandem with peaks in concentrations of anthropogenic pollution tracers $\mathrm{As}, \mathrm{Cd}, \mathrm{Ni}, \mathrm{Pb}$, $\mathrm{Sb}$ and $\mathrm{Sr}$. We recorded the second-highest concentrations $\left(664 \mu \mathrm{g} \mathrm{m}^{-3}\right.$ ) once again nearer the urban area of Jeddah during an intense large-scale dust storm that affected the entire Red Sea for five days during March 2017. In general, concentrations of TSP were uniformly spread across the entire Red Sea for the measurement dates; however, the random sampling during different times of year may introduce some bias in our observations.

Lim et al. (2018) recently reported annual mean concentrations of $\mathrm{PM}_{10}$ for a suburban site on the outskirts of
Table 1 Annual and seasonal summary statistics for total suspended particulates (TSP; $\mu \mathrm{g} \mathrm{m}^{-3}$ ) at the permanent and mobile sampling sites

\begin{tabular}{|c|c|c|c|c|c|c|c|c|c|c|}
\hline \multirow[t]{2}{*}{$\mu \mathrm{g} \mathrm{m}^{-3}$} & \multicolumn{5}{|c|}{ Permanent (onshore) } & \multicolumn{5}{|c|}{ Mobile (off-shore) } \\
\hline & Mean & SD & Median & Min & Max & Mean & SD & Median & Min & $\operatorname{Max}$ \\
\hline Total & 125 & 197 & 89 & 11 & 2389 & 108 & 193 & 63 & 7 & 1619 \\
\hline Autumn & 111 & 60 & 94 & 33 & 333 & 137 & 290 & 61 & 30 & 1619 \\
\hline Winter & 104 & 75 & 77 & 37 & 444 & 91 & 93 & 61 & 30 & 395 \\
\hline Spring & 164 & 385 & 90 & 11 & 2389 & 106 & 48 & 66 & 8 & 664 \\
\hline Summer & 124 & 106 & 85 & 43 & 646 & 63 & 130 & 53 & 7 & 200 \\
\hline
\end{tabular}



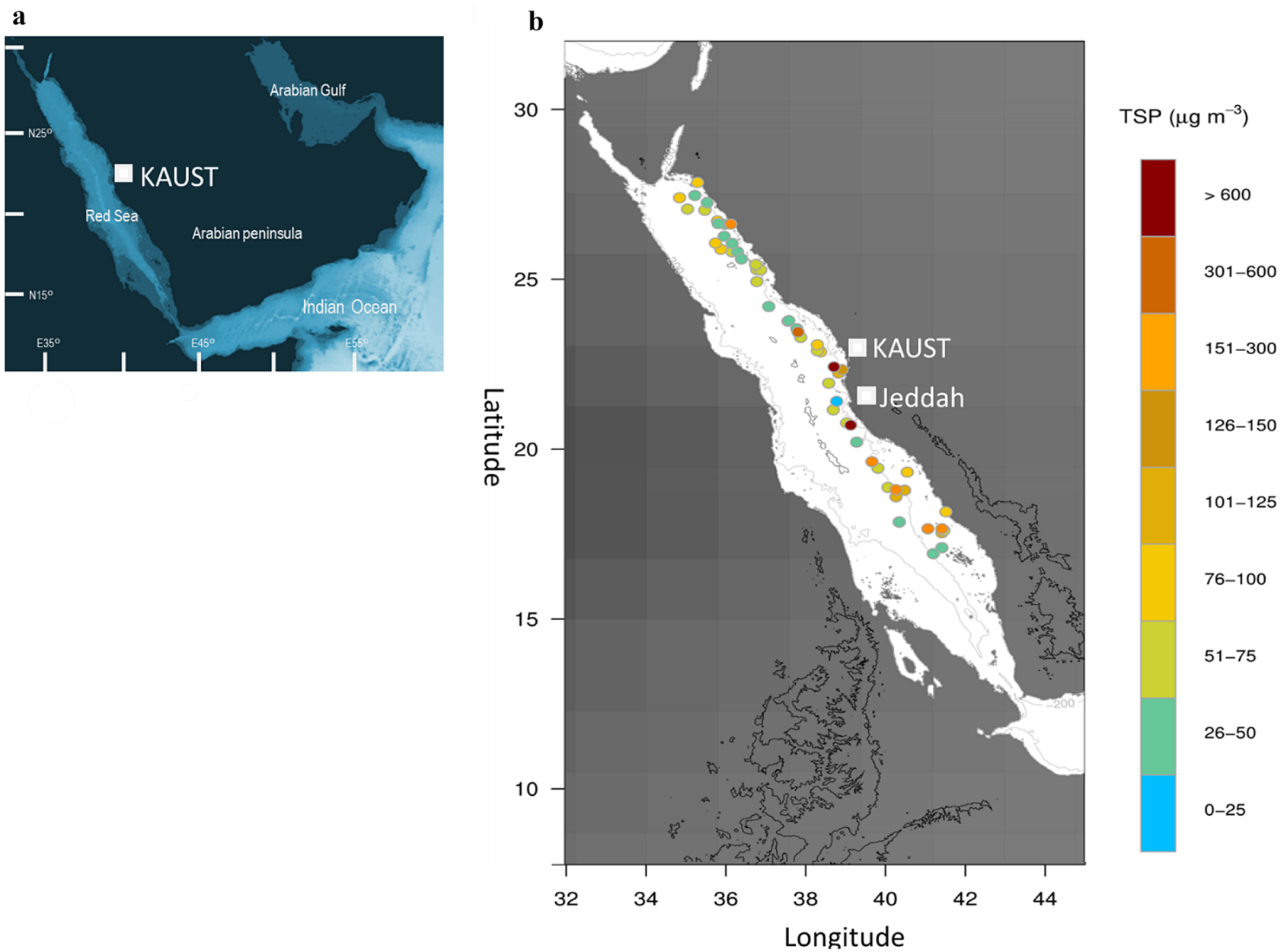

Fig. 3 a Location of King Abdullah University of Science and Technology (KAUST) on the Red Sea coast and $\mathbf{b}$ average concentrations of TSP $\left(\mu \mathrm{g} \mathrm{m}^{-3}\right)$ along the Red Sea for the mobile site, taken off-shore on the research vessel Thuwal between Feb 2016 and July 2017

Jeddah of $107.8 \pm 72.6 \mu \mathrm{g} \mathrm{m}^{-3}$, which are comparable to the TSP concentrations we measured at the permanent site $\left(125 \pm 197 \mu \mathrm{g} \mathrm{m}^{-3}\right)$, indicating that a large proportion of TSP for the region (86\%) exists as particles less than $10 \mu \mathrm{m}$ in diameter. Particles $>10 \mu \mathrm{m}$ have shorter atmospheric lifetimes as a result of faster depositional velocities but can be influential on a local scale, especially during dust events under high wind speeds. Lim et al. (2018) also observed a seasonal maximum in spring with $\mathrm{PM}_{10}$ of $114 \mu \mathrm{g} \mathrm{m}^{-3}$ (relative to our $164 \mu \mathrm{g} \mathrm{m}^{-3} \mathrm{TSP}$; Table 1). This spring maximum in average concentrations is a result of more frequent and intense dust storms when maximum dust emissions occur, especially for the Northern Red Sea (Anisimov et al. 2017). Anisimov et al. (2017) also observed that the total dust emissions and dust emission frequency were at their lowest during autumn and winter across the entire Red Sea, explaining the low mean concentrations for these seasons in our study.

The most abundant metal across both sites was $\mathrm{Na}$, with mean concentrations of $31 \pm 29$ and $241 \pm 846 \mu \mathrm{g} \mathrm{m}^{-3}$ at the permanent site and mobile site, respectively (Table 2), and is at least threefold more abundant in TSP relative to the next most abundant metal, $\mathrm{Ca}$. The primary source of $\mathrm{Na}$ in our samples is seawater spray, which explains the almost eight-fold increase of $\mathrm{Na}$ concentrations in the mobile (off-shore) site relative to the permanent onshore site. Ca was the next most abundant constituent at both sites, both in average and in median concentrations, followed by S (likely of anthropogenic origin with some marine input), and then metals predominantly of natural origin $\mathrm{Al}, \mathrm{Fe}, \mathrm{Sn}, \mathrm{K}$. Of the trace metal concentrations (bottom half of Table 2; $\mathrm{ng} \mathrm{m}^{-3}$ ), $\mathrm{P}$ was the most abundant constituent, with mean concentrations of $101 \pm 138$ and $221 \pm 475 \mathrm{ng} \mathrm{m}^{-3}$ for the permanent and mobile site, respectively, followed by $\mathrm{Zn}, \mathrm{Mn}$ and $\mathrm{Sr}$ (Table 2). Toxic metals, such as $\mathrm{As}, \mathrm{Cr}$, and $\mathrm{Pb}$, were for the most part, in measurable quantities and were all higher in the mobile off-shore site samples relative to the permanent site. The elevated concentrations of anthropogenic trace metals at the mobile site are likely to be a result of the capture of pollution from industrial and urban areas along the 
Table 2 Summary statistics for element constituents of TSP at the permanent and mobile sampling sites

\begin{tabular}{|c|c|c|c|c|c|c|c|c|c|c|c|c|}
\hline \multirow[b]{2}{*}{ Metal } & \multicolumn{5}{|c|}{ Permanent (onshore) } & \multicolumn{5}{|c|}{ Mobile (off-shore) } & \multirow{2}{*}{$\begin{array}{l}\text { Khodeir et al. (2012) } \\
\text { Jeddah }\left(\mathrm{PM}_{10}\right)\end{array}$} & \multirow{2}{*}{$\begin{array}{l}\text { Lim et al. (2018) } \\
\text { Jeddah }\left(\mathrm{PM}_{10}\right)\end{array}$} \\
\hline & Mean & SD & Median & Min & Max & Mean & SD & Median & Min & Max & & \\
\hline \multicolumn{13}{|c|}{$\mu \mathrm{g} \mathrm{m}^{-3}$} \\
\hline TSP & 125 & 197 & 89 & 11 & 2389 & 108 & 193 & 63 & 7 & 1619 & $87.3 \pm 47.3$ & $107.8 \pm 72.6$ \\
\hline $\mathrm{Al}$ & 5.7 & 10.3 & 2.5 & 0.2 & 85.5 & 4.1 & 7.5 & 2.1 & 0.2 & 51.6 & $3.3 \pm 2.6$ & $2.9 \pm 1.6$ \\
\hline $\mathrm{Ca}$ & 9.1 & 14.6 & 6.6 & 0.4 & 15.4 & 26.9 & 89.1 & 7.7 & 73.0 & 70.4 & $4.4 \pm 2.2$ & $6.2 \pm 5.8$ \\
\hline $\mathrm{Fe}$ & 3.1 & 5.2 & 1.6 & 0.05 & 42.7 & 3.4 & 6.4 & 1.6 & 0.08 & 35.6 & $3.1 \pm 2.8$ & $3.8 \pm 3.1$ \\
\hline $\mathrm{K}$ & 1.6 & 2.4 & 0.8 & 0.06 & 19.6 & 1.1 & 1.7 & 0.6 & 0.04 & 10.4 & $0.7 \pm 0.4$ & $1.1 \pm 0.8$ \\
\hline $\mathrm{Mg}$ & 2.4 & 3.0 & 1.8 & 0.2 & 30.2 & 1.8 & 4.4 & 0.9 & 0.06 & 37.5 & $1.4 \pm 0.8$ & $1.4 \pm 0.6$ \\
\hline $\mathrm{Na}$ & 31 & 29 & 21 & 0.1 & 156 & 240 & 846 & 10 & 1.0 & 4757 & $1.6 \pm 0.8$ & $1.6 \pm 0.6$ \\
\hline$S$ & 6.5 & 6.1 & 5.1 & 0.08 & 64.5 & 4.1 & 3.8 & 2.5 & 0.1 & 17.6 & $3.5 \pm 1.1$ & $3.4 \pm 1.5$ \\
\hline $\begin{array}{c}\mathrm{Sn} \\
\mathrm{ng} \mathrm{m}^{-3}\end{array}$ & 2.5 & 4.2 & 1.4 & 1.6 & 44.5 & 1.3 & 2.4 & 0.6 & 0.001 & 13.5 & & \\
\hline As & 2.1 & 1.9 & 1.6 & 0.06 & 11.2 & 6.8 & 18.7 & 2.5 & 0.02 & 141 & $10 \pm 16$ & $25.9 \pm 32.6$ \\
\hline $\mathrm{Cd}$ & 0.2 & 0.4 & 0.2 & 0.006 & 2.0 & 0.5 & 1.3 & 0.2 & 0.02 & 8.9 & $98 \pm 85$ & $176.8 \pm 125.5$ \\
\hline $\mathrm{Cr}$ & 22.2 & 42.9 & 15.0 & 0.8 & 411 & 49.4 & 242 & 7.4 & 0.4 & 1917 & $8.8 \pm 7.8$ & $9.8 \pm 8.9$ \\
\hline $\mathrm{Cu}$ & 5.6 & 8.9 & 3.0 & 0.1 & 59.9 & 12.2 & 45.2 & 2.9 & 0.2 & 325 & $18 \pm 14$ & $26.0 \pm 14.6$ \\
\hline $\mathrm{Mn}$ & 58.1 & 89.5 & 30.5 & 5.1 & 653 & 52.9 & 93.9 & 27.1 & 0.4 & 538 & $98 \pm 81$ & $103.6 \pm 66.8$ \\
\hline $\mathrm{Ni}$ & 12.2 & 15.7 & 8.9 & 0.8 & 141 & 44.7 & 147 & 15.5 & 1.2 & 1189 & $11 \pm 5.6$ & $11.1 \pm 7.2$ \\
\hline $\mathrm{P}$ & 101 & 138 & 62.4 & 8.7 & 1206 & 221 & 475 & 99.3 & 8.3 & 2809 & $160 \pm 62$ & \\
\hline $\mathrm{Pb}$ & 26.5 & 92.0 & 9.8 & 0.1 & 1038 & 34.3 & 87.8 & 12.0 & 0.7 & 578 & $200 \pm 420$ & $878.3 \pm 1702$ \\
\hline $\mathrm{Sb}$ & 3.1 & 3.3 & 1.9 & 0.03 & 30 & 9.3 & 24.7 & 3.5 & 0.3 & 142 & $27 \pm 15$ & \\
\hline $\mathrm{Sr}$ & 37.9 & 53.3 & 29.2 & 3.0 & 578 & 35.0 & 65.8 & 15.0 & 1.7 & 388 & & \\
\hline $\mathrm{V}$ & 20.3 & 18.4 & 16.3 & 0.6 & 173 & 11.4 & 8.1 & 9.7 & 0.4 & 56.5 & $31 \pm 14$ & $29.3 \pm 15.6$ \\
\hline $\mathrm{Zn}$ & 78.3 & 71.5 & 57 & 0.5 & 511 & 237 & 942 & 47.9 & 0.1 & 7919 & $77 \pm 120$ & $74.5 \pm 93.1$ \\
\hline
\end{tabular}

Top half of table in $\mu \mathrm{g} \mathrm{m}^{-3}$, bottom half in $\mathrm{ng} \mathrm{m}^{-3}$

coastline of the Red Sea, as well as from shipping emissions, as the Red Sea is one of the main highways for global shipping transport. We found, however, no significant $(P>0.05)$ latitudinal gradient in TSP or metal concentrations in TSP for the off-shore sampling site (Fig. 4).

The metal concentrations for major components $\mathrm{Al}, \mathrm{Ca}$, $\mathrm{Fe}, \mathrm{K}, \mathrm{Mg}$, Na, and $\mathrm{S}$ reported here (Table 2) compare well with those reported for $\mathrm{PM}_{10}$ in studies conducted in suburban areas of Jeddah by Khodeir et al. (2012) and Lim et al. (2018; Table 2). These similarities indicate the regional nature of these metals, which are not significantly impacted by urban emissions or anthropogenic activities, except for $\mathrm{S}$, which is typically of anthropogenic origin. Lim et al. (2018) found a decreasing trend from weekdays to weekends for the major metals listed above; however, this difference is most likely a result of reduced construction activity and resuspended road dust from traffic at the weekends.

Concentrations of trace metals $\left(\mathrm{ng} \mathrm{m}^{-3}\right.$; Table 2) were all lower at the permanent onshore site relative to the mobile off-shore site except for Mn (typically of crustal origin), $\mathrm{Sr}$ and V. However, compared to data reported by Khodeir et al. (2012) and Lim et al. (2018) for specific anthropogenic metals $\mathrm{As}, \mathrm{Cd}, \mathrm{Pb}$, and $\mathrm{Zn}$ in $\mathrm{PM}_{10}$ (Table 2), our concentrations at both sites are substantially lower, such as at the mobile site, for As $\left(6.8 \pm 18.7 \mathrm{ng} \mathrm{m}^{-3}\right), \mathrm{Cd}\left(0.5 \pm 1.3 \mathrm{ng} \mathrm{m}^{-3}\right)$ and $\mathrm{Pb}$ $\left(34.3 \pm 87.8 \mathrm{ng} \mathrm{m}^{-3}\right)$, indicating that these metals can be attributed to urban emissions from within the greater Jeddah region.

The enrichment factor values for each element at the permanent and mobile stations are summarised in Table 3. EF values that are $<2$ are generally considered natural and a result of crustal erosion, i.e., primary emissions of a natural source with minimal anthropogenic enrichment. EF values in the range $2-5$ are considered moderately enriched relative to natural background levels, 5-40 are significantly enriched, and values $>40$ are extremely enriched (Hu and Gao 2008). The elements that showed little or no enrichment were typical crustal constituents, such as $\mathrm{Al}, \mathrm{Fe}, \mathrm{K}, \mathrm{Mg}$ and $\mathrm{Mn}$. In contrast, we found elements of anthropogenic origin and considered toxic, such as $\mathrm{As}, \mathrm{Cd}$, and $\mathrm{Pb}$, to be moderately to extremely enriched, in both the permanent and mobile sites, indicating a substantial source of these controlled metals along the Red Sea. S was found to be the most enriched element by some margin for both sites. The source of $S$ for this region will almost certainly be from fuel oil combustion 


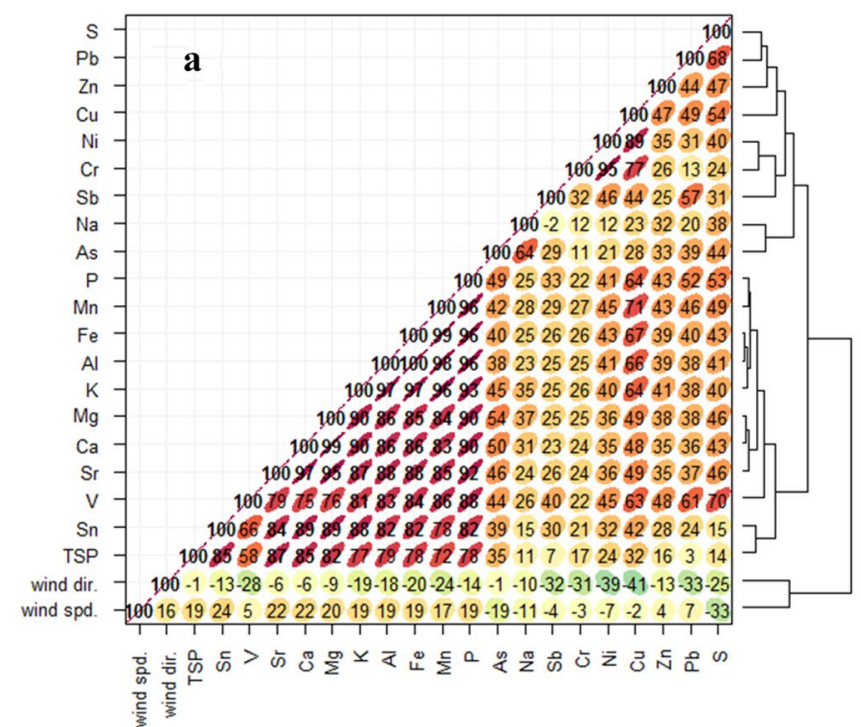

Fig. 4 Correlation matrices for all measured metal and TSP concentrations at the a permanent site and $\mathbf{b}$ mobile site. Dark red to yellow indicates decreasing correlation, and green-hued colours indicate negative correlations. High Pearson correlation coefficients $(r)$ are

Table 3 Enrichment factors (EFs) for elements in TSP for the permanent and mobile sites

\begin{tabular}{lll}
\hline $\mathrm{EF}$ & $\begin{array}{l}\text { Permanent } \\
\text { (onshore) }\end{array}$ & $\begin{array}{l}\text { Mobile } \\
\text { (off- } \\
\text { shore) }\end{array}$ \\
\hline $\mathrm{Al}$ & 1.4 & 0.9 \\
$\mathrm{As}$ & 24 & 72 \\
$\mathrm{Ca}$ & 3.8 & 10.3 \\
$\mathrm{Cd}$ & 33 & 67 \\
$\mathrm{Cr}$ & 3.3 & 6.7 \\
$\mathrm{Cu}$ & 1.7 & 3.4 \\
$\mathrm{Fe}$ & 1.1 & 1.0 \\
$\mathrm{~K}$ & 2.1 & 1.4 \\
$\mathrm{Mg}$ & 1.7 & 1.2 \\
$\mathrm{Mn}$ & 1.1 & 0.9 \\
$\mathrm{Na}$ & 28 & 199 \\
$\mathrm{Ni}$ & 2.8 & 9.4 \\
$\mathrm{P}$ & 2.1 & 4.2 \\
$\mathrm{~Pb}$ & 55 & 65 \\
$\mathrm{~S}$ & 319 & 187 \\
$\mathrm{Sr}$ & 2.2 & 1.9 \\
$\mathrm{~V}$ & 2.2 & 1.1 \\
$\mathrm{Zn}$ & 21 & 57 \\
\hline & &
\end{tabular}

through power generation, desalination and shipping emissions, and a probable significant portion as secondary sulphate owing to the high solar irradiance.

The relationships between TSP and metal concentrations are shown in the correlation matrices for the permanent site (including wind speed and direction; Fig. 4a) and the mobile

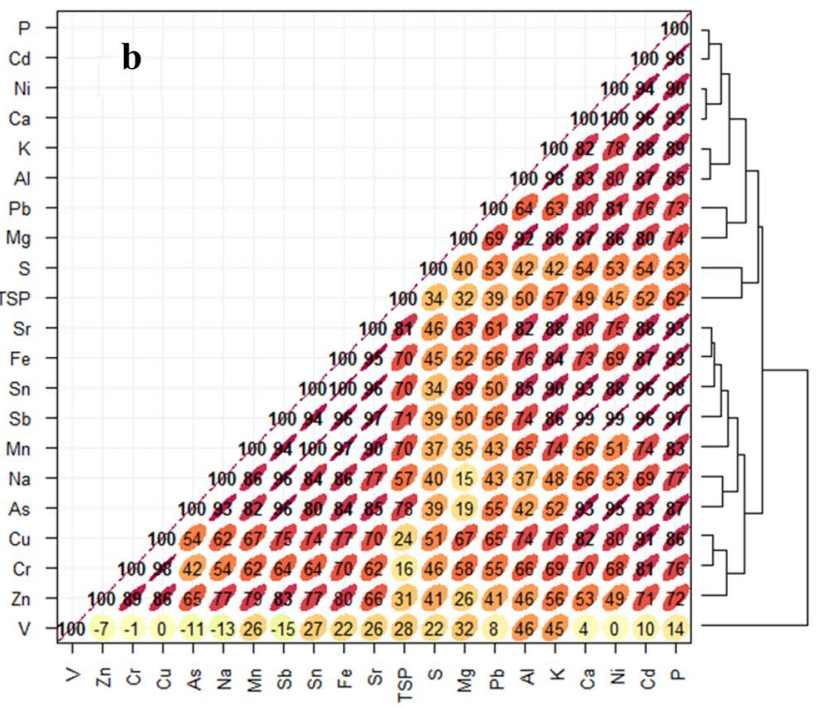

shown in bold type with a narrow red ellipse, and weak $r$ values are shown in circular yellow ellipses. Note that $r$ values are $<0$; the decimal point is not visible

site (Fig. 4b). There was a strong correlation between elements of crustal origin $\mathrm{Al}, \mathrm{Fe}, \mathrm{Mn}$, and $\mathrm{Sn}$, as expected. However, the positive correlation between almost all of the individual constituents indicates that the air mass both at KAUST and across the entire Red Sea is well mixed with both natural sources, such as crustal material and anthropogenic metals. There appears to be a meaningful correlation at the permanent site between wind direction and several anthropogenic elements $(\mathrm{S}, \mathrm{Pb}, \mathrm{Zn}, \mathrm{Ni}, \mathrm{Cu}, \mathrm{Cr})$, occurring when breezes occasionally reach our site from the south, thus carrying urban pollution from Jeddah. Source apportionment analysis by PMF will help resolve these possible individual sources, which we discuss anon.

We used 18 TSP chemical components with a signal-tonoise ratio $(S / N)$ greater than 0.2 to identify various potential sources of contaminants at the permanent and mobile site. We identified four sources of TSP by PMF analysis. Figure 5 shows the source profiles and the percentage contribution of each metal's ambient concentration apportioned by each source for the permanent site (Fig. 5a) and the mobile site (Fig. 5b). Although the mobile site collected much fewer samples than the permanent site (81 vs. 157 cases, respectively), four identical sources were identified for the mobile site, highlighting the influence of these sources across the Red Sea basin and the robustness of the approach used to apportion sources to TSP.

The four TSP sources identified, in order of contribution to the total mass at the permanent station, were fuel oil combustion/secondary sulphate $\left(33 \% ; 34.7 \mu \mathrm{g} \mathrm{m}^{-3}\right)$, 
Fig. 5 a, b Source profiles $\left(\mu \mathrm{g}^{-1}\right)$ identified for TSP measured at the permanent onshore site (a) and the offshore mobile site (b). All available TSP samples $[157$ cases $(\mathbf{a})$ and 81 cases (b)] were included in the analysis. The mass of each species apportioned to each factor is represented by the blue bar (left axis), and the percent of each species apportioned to each factor is represented by the red square (right axis)
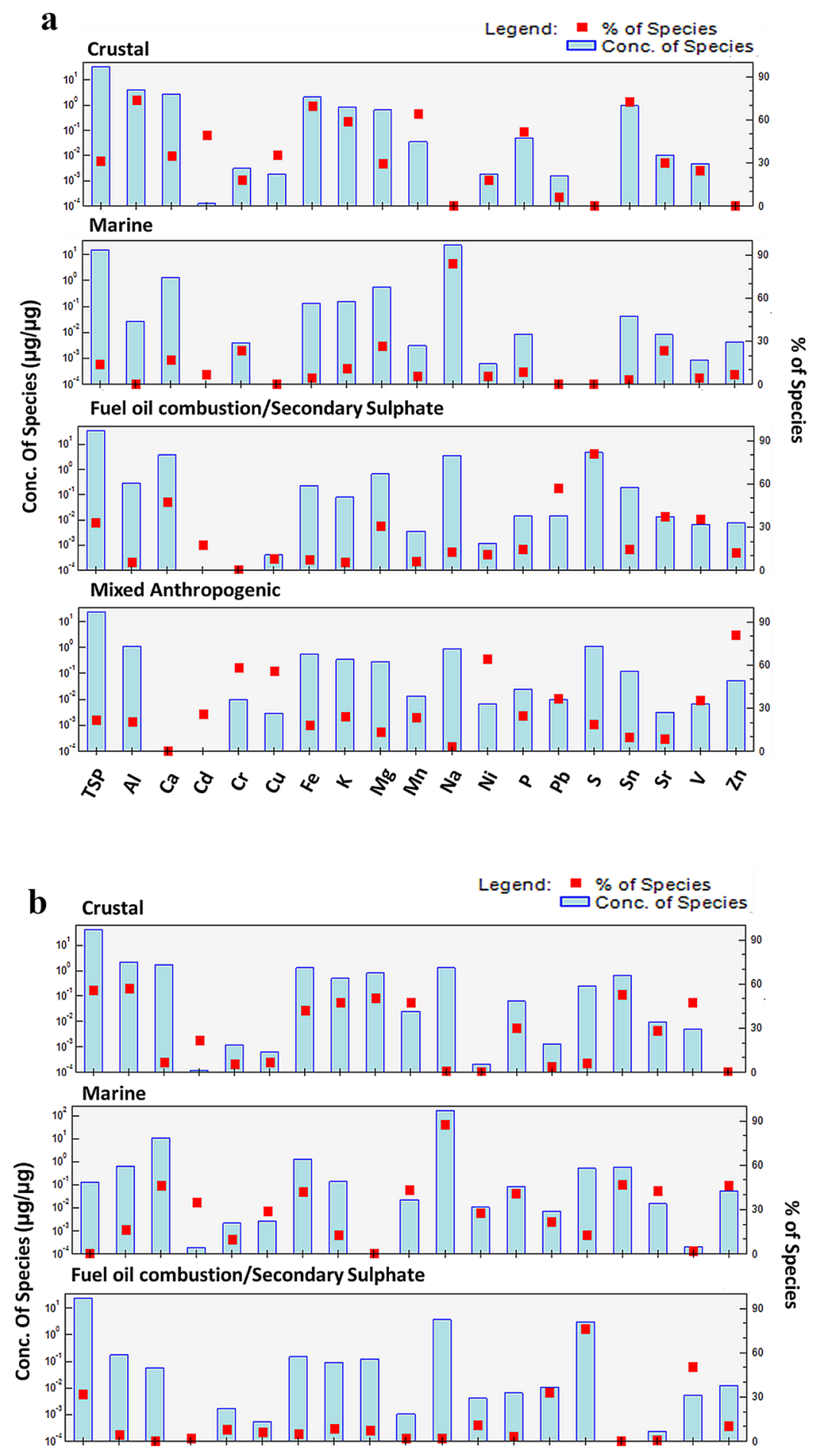

Mixed Anthropogenic

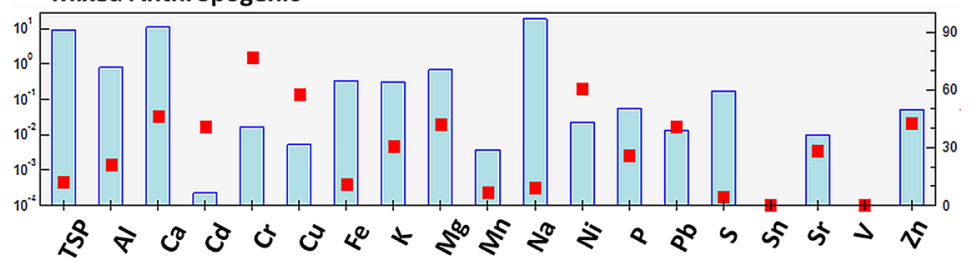




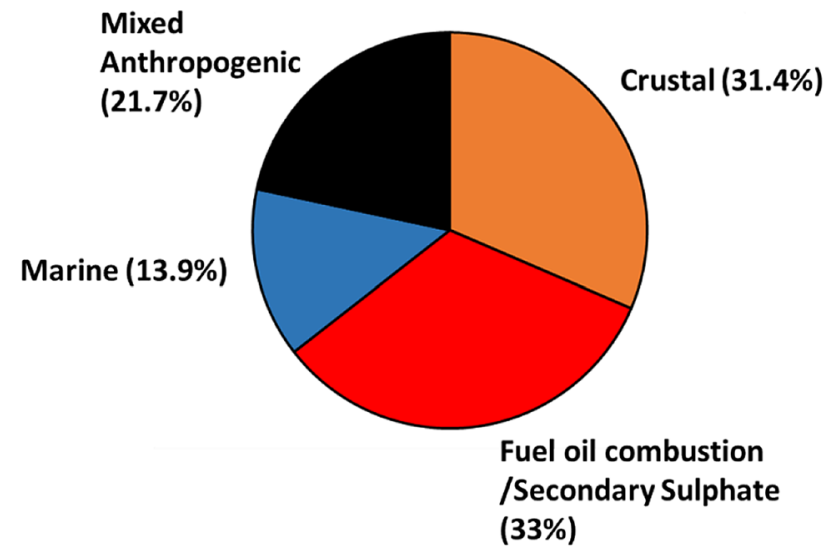

Fig. 6 The average contribution of each source to TSP $\left(\mu \mathrm{g} \mathrm{m}^{-3}\right)$ identified by the PMF solution

crustal $\left(31.4 \% ; 33 \mu \mathrm{g} \mathrm{m}^{-3}\right)$, mixed anthropogenic $(21.7 \%$; $22.7 \mathrm{\mu g} \mathrm{m}^{-3}$ ) and marine (13.9\%; $14.5 \mu \mathrm{g} \mathrm{m}^{-3}$; Fig. 6$)$.

Note that the sum of the contribution of each source does not equal the total mass of TSP because a fraction of the mass was undetermined, i.e., the sum of the mass of each source identified was $104.9 \mu \mathrm{g} \mathrm{m}^{-3}$ compared to average TSP concentrations of $125 \mu \mathrm{g} \mathrm{m}^{-3}$.

The fuel-oil combustion/secondary sulphate source is identifiable by the presence of $\mathrm{S}$ and $\mathrm{V}$, which are typical emission tracers for the combustion of oil. Indeed, 91\% of the variance of $\mathrm{S}$ is explained by this source alone. Noteworthy is the absence of $\mathrm{Ni}$ and the significant presence of $\mathrm{Pb}$ in this source (explaining 57\% of the variance of $\mathrm{Pb}$ ). $\mathrm{Ni}$ is a tracer metal for fuel oil combustion usually present with $\mathrm{V}$ and has been identified in previous source apportionment studies in Jeddah that identified fuel-oil combustion as a source (Khodeir et al. 2012; Lim et al. 2018). Both studies identified a similar fuel-oil combustion source containing S, V and Ni. However, Khodeir et al. (2012) highlighted that $\mathrm{Ni}$ and $\mathrm{V}$ were weakly correlated, indicating that these elements may not be exclusively of the same source in this region. Similarly to our study, Lim et al. (2018) identified a source with $\mathrm{S}$ and $\mathrm{Pb}$ in $\mathrm{PM}_{10}$, which they attributed to traffic emissions, even though $\mathrm{Pb}$ as an additive to gasoline has been prohibited in Saudi Arabia since 2001, and V and $\mathrm{Ni}$ are not associated with traffic emissions. Abulfaraj et al. (1990) reported that before the phase-out of leaded gasoline, concentrations of $\mathrm{Pb}$ in TSP were as high as $1270 \mathrm{ng} \mathrm{m}^{-3}$, reducing to $73.3 \mathrm{ng} \mathrm{m}^{-3}$ in $\mathrm{PM}_{2.5}$ following the phase-out of leaded fuel (Aburas et al. 2011). Aburas et al. (2011) outline some potential sources of $\mathrm{Pb}$ for the Jeddah region, including heavy-duty traffic and several factories that process $\mathrm{Pb}$ and recycle batteries. They attribute very high consumption of fuel by local industries and water desalination plants, with limited scrubbing for contaminants, to be a major source of $\mathrm{Pb}$, which explains the presence of $\mathrm{Pb}$ in our fuel-oil combustion source.

$\mathrm{S}$ is likely to have several sources in this region, such as primary emissions of $\mathrm{S}$ from the combustion of fuel oil for power production and desalination. Furthermore, the Red Sea is one of the busiest shipping lanes in the world, and shipping emissions are a significant global source of atmospheric S. However, the presence of secondary sulphate, formed in the atmosphere from primary $\mathrm{S}$ emissions, is likely to be significant for this region, with high $\mathrm{S}$ emissions and intense, year-round insolation. Secondary sulphate can form and travel far from emission sources, accumulating in the atmosphere over long periods. Furthermore, secondary sulphate particles have a significant atmospheric cooling effect by reflecting incoming solar radiation. This atmospheric forcing, coupled with high dust concentrations, could indicate a strong net cooling effect across this region of the globe. Of further interest is the absence of $\mathrm{Ni}$ in this factor, which is typically emitted alongside V from a fuel-oil combustion source. Our receptor model did not identify $\mathrm{S}$ in the Marine source, indicating that marine sulphate is not influential in the Red Sea.

As expected, the Crustal source is a dominant constituent of atmospheric particles for the desert region of the Red Sea basin. It is identifiable by typical crustal earth metals Al, Fe, K, Mg, Mn, P and Sn (Amato et al. 2009), accounting for $31.4 \%$ of TSP. This source explains the majority of the variance of $\mathrm{Fe}$ and $\mathrm{P}$ (and presumably $\mathrm{Si}$, which is of crustal origin but was not measured in this work). The permanent presence of dust particles in the atmosphere in this desert region, from local sources and long-range transport, means there is significant mixing between dust-laden air masses and other sources of pollution; thus, the contribution of the crustal source to the overall TSP concentrations may be underestimated. The persistent presence of crustal material in the atmosphere may be of importance to Red Sea ecosystems. Marine primary production is limited by the availability of nutrients Fe, P, N and Si (Okin et al. 2011), especially for the Red Sea, which is especially oligotrophic. The crustal source identified here is rich in $\mathrm{Fe}$, and to a lesser extent $\mathrm{P}$, and may provide a vital source of $\mathrm{Fe}$ for iron-deficient marine ecosystems.

The marine source is easily identifiable by $\mathrm{Na}$, which is an obvious significant source for our coastal site and off-shore station on-board the research vessel.

Finally, the mixed anthropogenic source was characterised by the presence of tracers $\mathrm{Cr}, \mathrm{Cd}, \mathrm{Cu}, \mathrm{Ni}, \mathrm{Pb}, \mathrm{Sr}$, and $\mathrm{Zn}$, all of which are associated with anthropogenic activities, such as incineration $(\mathrm{Cu}, \mathrm{Zn}$; Morawska and Zhang 2002), traffic emissions ( $\mathrm{Zn}, \mathrm{Cu}, \mathrm{Sr}, \mathrm{Pb}$; López et al. 2011) and industrial emissions $(\mathrm{Cu}, \mathrm{Cd}, \mathrm{Cr}, \mathrm{Ni}, \mathrm{Zn}$; Cesari et al. 2016), and to some extent probably from oil-based 
and petroleum industry and water desalination, which are widespread and intense for this region.

\section{Conclusion}

This study is one of few existing studies describing the elemental composition and sources of total suspended atmospheric particulate matter for the Red Sea coastline and the Red Sea basin. Here, we reveal that anthropogenic emissions contributed over half of the total TSP load in a region that is already severely impacted by high atmospheric dust loads and intense dust storms. TSP concentrations are elevated throughout the year across the Red Sea region, with no evident seasonality in background levels. However, these already elevated background concentrations are compounded by severe dust storms that affect the mean ambient concentrations. Average TSP concentrations are highest in spring for our permanent sampling site on the Red Sea coastline when intense dust storms are most frequent. The transport of pollution severely impacts off-shore air quality near the urban area of Jeddah, where we measured extreme levels of pollution (on-board a research vessel) as a result of a persistent dust storm that mixed with urban emissions. These types of dust storms mixed with anthropogenic pollution episodes are frequent and of significant importance for epidemiological studies focusing on the health impacts of air pollution in the region. Using PMF source apportionment, we identified four major source profiles contributing to TSP concentrations. Crustal material is a significant source of particulates, contributing up to one-third of the total TSP loading, as a result of the resuspension of loose soil and dust particles from across the peninsula and the Sahara. We identified an equally important contribution of particulates from the combustion of oil. However, this source is also strongly characterised by $\mathrm{Pb}$, the precise source of which remains unclear. We also identified a significant contribution of anthropogenic pollution, identifiable by tracers $\mathrm{Cr}$, $\mathrm{Cu}, \mathrm{Ni}$ and $\mathrm{Zn}$. This study provides further evidence of the complex composition of atmospheric particulates for the region, which remains relatively understudied.

Most importantly, we have discovered that anthropogenic contributions double the already extreme levels of TSP in the region and add toxic heavy metals to an already polluted atmosphere, representing a significant health hazard in the region. The negative impact of air pollution on health is currently an area of intense focus. We provide evidence that the Red Sea region is continuously exposed to extremely high levels of dust particles, compounded by significant sources of anthropogenic pollution, producing a potentially hazardous atmospheric environment.
Acknowledgements The research in this publication was supported by King Abdullah University of Science and Technology, KAUST, through funding provided to CMD and the Red Sea Research Center. We thank CMOR staff for their assistance in deploying the sampling instruments and Vijayalaxmi Dasari for her help with laboratory analyses.

\section{Compliance with Ethical Standards}

Conflict of interest The author declares that there is no competing interest.

Open Access This article is licensed under a Creative Commons Attribution 4.0 International License, which permits use, sharing, adaptation, distribution and reproduction in any medium or format, as long as you give appropriate credit to the original author(s) and the source, provide a link to the Creative Commons licence, and indicate if changes were made. The images or other third party material in this article are included in the article's Creative Commons licence, unless indicated otherwise in a credit line to the material. If material is not included in the article's Creative Commons licence and your intended use is not permitted by statutory regulation or exceeds the permitted use, you will need to obtain permission directly from the copyright holder. To view a copy of this licence, visit http://creativecommons.org/licenses/by/4.0/.

\section{References}

Abulfaraj WH, Ahmed M, Mousli KM, Erturk F (1990) Measurement of ambient air lead concentrations in the city of Jeddah, Saudi Arabia. Environ Int 16:85-88

Aburas HM, Zytoon MA, Abdulsalam MI (2011) Atmospheric lead in PM2. 5 after leaded gasoline phase-out in Jeddah city, Saudi Arabia. Clean: Soil, Air, Water 39:711-719

Acosta F, Ngugi DK, Stingl U (2013) Diversity of picoeukaryotes at an oligotrophic site off the Northeastern Red Sea Coast. Aquat Biosyst 9:16

Alghamdi M, Khoder M, Harrison RM, Hyvärinen A-P, Hussein T, Al-Jeelani H, Abdelmaksoud A, Goknil M, Shabbaj I, Almehmadi $\mathrm{F}$ (2014) Temporal variations of $\mathrm{O}_{3}$ and $\mathrm{NO} x$ in the urban background atmosphere of the coastal city Jeddah, Saudi Arabia. Atmos Environ 94:205-214

Amato F, Pandolfi M, Escrig A, Querol X, Alastuey A, Pey J, Perez N, Hopke P (2009) Quantifying road dust resuspension in urban environment by multilinear engine: a comparison with PMF2. Atmos Environ 43:2770-2780

Anisimov A, Tao W, Stenchikov G, Kalenderski S, Prakash PJ, Yang Z-L, Shi M (2017) Quantifying local-scale dust emission from the Arabian Red Sea coastal plain. Atmos Chem Phys 17:993-1015

Brewin RJ, Raitsos DE, Dall'Olmo G, Zarokanellos N, Jackson T, Racault M-F, Boss ES, Sathyendranath S, Jones BH, Hoteit I (2015) Regional ocean-colour chlorophyll algorithms for the Red Sea. Remote Sens Environ 165:64-85

Brindley H, Osipov S, Bantges R, Smirnov A, Banks J, Levy R, Jish Prakash P, Stenchikov G (2015) An assessment of the quality of aerosol retrievals over the Red Sea and evaluation of the climatological cloud-free dust direct radiative effect in the region. J Geophys Res Atmos 120:10862-10878

Cesari D, Amato F, Pandolfi M, Alastuey A, Querol X, Contini D (2016) An inter-comparison of PM10 source apportionment using PCA and PMF receptor models in three European sites. Environ Sci Pollut Res 23:15133-15148 
Chaidez V, Dreano D, Agusti S, Duarte CM, Hoteit I (2017) Decadal trends in Red Sea maximum surface temperature. Sci Rep 7:8144

de Vries AJ, Tyrlis E, Edry D, Krichak S, Steil B, Lelieveld J (2013) Extreme precipitation events in the Middle East: dynamics of the Active Red Sea Trough. J Geophys Res Atmos 118:7087-7108

Edgell HS (2006) Arabian deserts: nature, origin and evolution. Springer Science and Business Media, Berlin

Engelbrecht JP, Stenchikov G, Prakash PJ, Lersch T, Anisimov A, Shevchenko I (2017) Physical and chemical properties of deposited airborne particulates over the Arabian Red Sea coastal plain. Atmos Chem Phys 17:11467-11490

Goudie AS, Middleton NJ (2006) Desert dust in the global system. Springer Science and Business Media, Berlin

Harrison RM, Alam MS, Dang J, Basahi J, Alghamdi MA, Ismail IM, Khoder M, Hassan IA (2016) Influence of petrochemical installations upon PAH concentrations at sites in Western Saudi Arabia. Atmos Pollut Res 7(6):954-960

Harrison RM, Bousiotis D, Mohorjy AM, Alkhalaf AK, Shamy M, Alghamdi M, Khoder M, Costa M (2017) Health risk associated with airborne particulate matter and its components in Jeddah, Saudi Arabia. Sci Total Environ 590-591:531-539

Hsu NC, Tsay S-C, King MD, Herman JR (2004) Aerosol properties over bright-reflecting source regions. IEEE Trans Geosci Remote Sens 42:557-569

Hu Z, Gao S (2008) Upper crustal abundances of trace elements: a revision and update. Chem Geol 253:205-221

Jish Prakash P, Stenchikov G, Kalenderski S, Osipov S, Bangalath $H$ (2015) The impact of dust storms on the Arabian Peninsula and the Red Sea. Atmos Chem Phys 15:199-222

Jish Prakash P, Stenchikov G, Tao W, Yapici T, Warsama B, Engelbrecht JP (2016) Arabian Red Sea coastal soils as potential mineral dust sources. Atmos Chem Phys 16:11991-12004

Kalenderski S, Stenchikov G, Zhao C (2013) Modeling a typical winter-time dust event over the Arabian Peninsula and the Red Sea. Atmos Chem Phys 13:1999-2014

Khodeir M, Shamy M, Alghamdi M, Zhong M, Sun H, Costa M, Chen L-C, Maciejczyk P (2012) Source apportionment and elemental composition of PM2.5 and PM10 in Jeddah City, Saudi Arabia. Atmos Pollut Res 3:331-340

Lelieveld J, Evans JS, Fnais M, Giannadaki D, Pozzer A (2015) The contribution of outdoor air pollution sources to premature mortality on a global scale. Nature 525:367
Lim CC, Thurston GD, Shamy M, Alghamdi M, Khoder M, Mohorjy AM, Alkhalaf AK, Brocato J, Chen LC, Costa M (2018) Temporal variations of fine and coarse particulate matter sources in Jeddah, Saudi Arabia. J Air Waste Manag Assoc 68:123-138

López ML, Ceppi S, Palancar GG, Olcese LE, Tirao G, Toselli BM (2011) Elemental concentration and source identification of PM10 and PM2. 5 by SR-XRF in Córdoba City, Argentina. Atmos Environ 45:5450-5457

Mahowald N, Albani S, Kok JF, Engelstaeder S, Scanza R, Ward DS, Flanner MG (2014) The size distribution of desert dust aerosols and its impact on the Earth system. Aeol Res 15:53-71

Morawska L, Zhang JJ (2002) Combustion sources of particles. 1. Health relevance and source signatures. Chemosphere 49:1045-1058

Okin GS, Baker AR, Tegen I, Mahowald NM, Dentener FJ, Duce RA, Galloway JN, Hunter K, Kanakidou M, Kubilay N (2011) Impacts of atmospheric nutrient deposition on marine productivity: Roles of nitrogen, phosphorus, and iron. Global Biogeochem. Cycles 25:GB2022. https://doi.org/10.1029/2010GB003858

Osipov S, Stenchikov G, Brindley H, Banks J (2015) Diurnal cycle of the dust instantaneous direct radiative forcing over the Arabian Peninsula. Atmos Chem Phys 15:9537-9553

Pope CA III, Burnett RT, Thun MJ, Calle EE, Krewski D, Ito K, Thurston GD (2002) Lung cancer, cardiopulmonary mortality, and long-term exposure to fine particulate air pollution. JAMA 287:1132-1141

Ramanathan V, Carmichael G (2008) Global and regional climate changes due to black carbon. Nat Geosci 1:221

Ramanathan V, Crutzen P, Kiehl J, Rosenfeld D (2001) Aerosols, climate, and the hydrological cycle. Science 294:2119-2124

Şen Z (2018) Standard Aerosol Optical Depth Index and application in the Middle East countries. Int J Glob Warm 16(1):39

Tanaka TY, Chiba M (2006) A numerical study of the contributions of dust source regions to the global dust budget. Glob Planet Change 52:88-104

Valavanidis A, Fiotakis K, Vlachogianni T (2008) Airborne particulate matter and human health: toxicological assessment and importance of size and composition of particles for oxidative damage and carcinogenic mechanisms. J Environ Sci Health Part C 26:339-362 